\title{
Corrigendum
}

\section{Conspecific interference by adults in an aphidophagous ladybird Propylea dissecta (Coleoptera: Coccinellidae): effect on reproduction}

\author{
G. Mishra and Omkar* \\ Ladybird Research Laboratory, Department of Zoology, University of \\ Lucknow, Lucknow 226 007, India
}

Bulletin of Entomological Research, Vol. 96(4), pp. 407-412

Physical and chemical interference in insects has the potential to modify both foraging as well as reproductive responses of an organism. The understanding of effect of interference in insects has been taken up by workers the world over. Though the role of physical interference in modifying foraging behaviour has been widely studied, its influence on reproductive behaviour is relatively less studied in ladybirds (Hemptinne \& Dixon, 1991; Hemptinne et al., 1992, 1993; Lemaitre, 1992; Doumbia et al., 1998).

Chemical interference and its role in reproductive behaviour of predatory insects, on the other hand, is widely accepted, with the first report being in chrysopids (Růžička, 1994). This study was followed by many others which verified the presence of oviposition deterring pheromones and allomones in larval tracks (R̛̊žička, 1996, 1997a,b, 1998, 2001a,b, 2002, 2003; Doumbia et al., 1998; Růžička \& Havelka, 1998; Takizawa et al., 2000; Yasuda et al., 2000; Hemptinne et al., 2001; Fréchette et al., 2003).

Most of these studies have paid attention to larval interference (physical as well as chemical) and not adult interference with the exception of one on adult tracks (Doumbia et al., 1998). The findings of Mondor \& Warren (2000) that Harmonia axyridis adults make fewer visits to areas previously searched by others is probably indicative of the presence of chemicals in adult tracks.

In the work contained in the above communication (Mishra \& Omkar, 2006), we have assessed the role of physical and chemical interference by adults, if any, on reproduction in an aphidophagous ladybird beetle, Propylea

*Author for correspondence

E-mail: omkaar55@hotmail.com dissecta. We found that both physical and chemical interference by adults had a negative influence on reproduction.

There has been an error in citation of references on page 408 column 1 line 1, page 411 column 1 line 23, and the penultimate line of the discussion. Hemptinne et al. (1992, 1993) have worked on the role of physical presence of larvae and larval odour and not on the larval tracks as mentioned at these points. To the best of our knowledge, Růžička (1994) is the first worker to have identified the presence of oviposition-deterring pheromones in predatory insects.

The above inadvertent error occurred owing to the use of cross references, which is highly regretted. The references of Hemptinne et al. (1992) and (1993) were taken as a cross reference from Hemptinne et al. (2001) and Doumbia et al. (1998) and, thus, inadvertently misinterpreted.

\section{References}

Doumbia, M., Hemptinne, J.L. \& Dixon, A.F.G. (1998) Assessment of patch quality by ladybeetles: role of larval tracks. Oecologia 113, 197-202.

Fréchette, B., Alauzet, C. \& Hemptinne, J.L. (2003) Oviposition behaviour of the two-spot ladybird beetle Adalia bipunctata (L.) (Coleoptera: Coccinellidae) on plants with conspecific larval tracks. Arquipélago-Life and Marine Science, Supplement 5, 73-77.

Hemptinne, J.L. \& Dixon, A.F.G. (1991) Why ladybirds have generally been so ineffective in biological control. pp. 149-245 in Polgar, L., Chambers, R.J., Dixon, A.F.G. \& Hodek, I. (Eds) Behaviour and impact of Aphidophaga. The Hague, SPB Academic Publishing. 
Hemptinne, J.L., Dixon, A.F.G. \& Coffin, J. (1992) Attack strategy of ladybird beetles (Coccinellidae): factors shaping their numerical response. Oecologia 90, 238-245.

Hemptinne, J.L., Dixon, A.F.G., Doucet, J.L. \& Petersen, J.E. (1993) Optimal foraging by hoverflies (Diptera: Syrphidae) and ladybirds (Coleoptera: Coccinellidae): mechanisms. European Journal of Entomology 90, 451-455.

Hemptinne, J.L., Lognay, J., Doumbia, M. \& Dixon, A.F.G. (2001) Chemical nature and persistence of the oviposition deterring pheromone in the tracks of the larvae of the two spot ladybird, Adalia bipunctata (Coleoptera: Coccinellidae). Chemoecology 11, 43-47.

Lemaitre, D. (1992) Stimulation et regulation de la ponte de la coccinelle coccidiphage Cryptolaemus montrouzieri Mulsant. 70 pp. Thesis, Universite Libre de Bruxelles.

Mondor, E.B. \& Warren, J.L. (2000) Unconditioned and conditioned responses to colour in the predatory coccinellid, Harmonia axyridis (Coleoptera: Coccinellidae). European Journal of Entomology 97, 463-467.

Mishra, G. \& Omkar (2006) Conspecific interference by adults in an aphidophagous ladybird Propylea dissecta (Coleoptera: Coccinellidae): effect on reproduction. Bulletin of Entomological Research 96, 407-412.

Růžička, Z. \& Havelka, J. (1998) Effects of oviposition-deterring pheromone and allomones on Aphidoletes aphidimyza (Diptera: Cecidomyiidae). European Journal of Entomology 95, 211-216.

Růžička, Z. (1994) Oviposition-deterring pheromone in Chrysopa oculata (Neuroptera: Chrysopidae). European Journal of Entomology 91, 361-370.

Růžička, Z. (1996) Oviposition-deterring pheromone in chrysopids: intra- and interspecific effects. European Journal of Entomology 93, 161-166.
Růžička, Z. (1997a) Persistence of the oviposition-deterring pheromone in Chrysopa oculata (Neuroptera: Chrysopidae). Entomophaga 42, 107-112.

Růžička, Z. (1997b) Recognition of oviposition-deterring allomones by aphidophagous predators (Neuroptera: Chrysopidae, Coleoptera: Coccinellidae). European Journal of Entomology 94, 431-434.

Růžička, Z. (1998) Further evidence of oviposition-deterring allomone in chrysopids (Neuroptera: Chrysopidae). European Journal of Entomology 95, 35-39.

Růžička, Z. (2001a) Oviposition responses of aphidophagous coccinellids to tracks of ladybird (Coleoptera: Coccinellidae) and lacewing (Neuroptera: Chrysopidae) larvae. European Journal of Entomology 98, 183-188.

Růžička, Z. (2001b) Response of chrysopids (Neuroptera) to larval tracks of aphidophagous coccinellids (Coleoptera). European Journal of Entomology 98, 283-285.

Růžička, Z. (2002) Persistence of deterrent larval tracks in Coccinella septempunctata, Cycloneda limbifer and Semiadalia undecimnotata (Coleoptera: Coccinellidae). European Journal of Entomology 99, 471-475.

Růžička, Z. (2003) Perception of oviposition-deterring larval tracks in aphidophagous coccinellids Cycloneda limbifer and Ceratomegilla undecimnotata (Coleoptera: Coccinellidae). European Journal of Entomology 100, 345-350.

Takizawa, T., Yasuda, H. \& Agarwal, B.K. (2000) Effects of parasitized aphids (Homoptera: Aphididae) as food on larval performance of three predatory ladybirds (Coleoptera: Coccinellidae). Applied Entomology and Zoology 35, 467-472.

Yasuda, H., Takagi, T. \& Kogi, K. (2000) Effects of conspecific and heterospecific larval tracks on the oviposition behaviour of the predatory ladybird, Harmonia axyridis (Coleoptera: Coccinellidae). European Journal of Entomology 97, 551-553. 